\title{
Some antidiabetic medicinal plants used by traditional healers in Ado Ekiti, Nigeria
}

\author{
Akharaiyi $\mathrm{FC}^{1}$, Akinyemi $\mathrm{AJ}^{2}$, Isitua $\mathrm{CC}^{1}$, Ogunmefun $\mathrm{OT}^{1}$, Opakunle $\mathrm{SO}^{3}$, Fasae $\mathrm{JK}^{4}$ \\ Biological Sciences Department, Afe Babalola University, Ado Ekiti, Nigeria. akharaiyifc@abuad.edu.ng
}

\begin{abstract}
OBJECTIVES: The work described plants collection, preparation and administration for diabetes cure in Ado Ekiti in Nigeria.

METHODS: Twenty three plant samples were identified for the use in the treatment of diabetes by the herbalists. The plants that are common among the healers are Anthocleista djalonensis, Vernonia amygdalina, Ocimum gratissimum, Momordica charantia.

RESULTS: The most preferred method of preparation by the healers is concoction and decoction of fresh leaves, stem bark and roots. However, for emergency sake, some healers dried these plant parts, ground to smooth powder and packaged in brown bottles or in nylon which are either sold or given to people, but must be soaked in cold or warm water before use.

CONCLUSION: The use of medicinal plants in healing diabetes is a common practice by traditional healers in Ado Ekiti and never treat their patients in conjunction with modern medicines (Ref. 4). Text in PDF www.elis.sk. KEY WORDS: traditional, plants, Ado Ekiti, diabetes, medicine.
\end{abstract}

\section{Introduction}

Diabetes is now a disease that affects 371 million people worldwide, and 187 million of them do not even know they have the disease, according to the International Diabetes Federation $(1,2,3,4)$.

The study was conducted in Ado metropolis of Ekiti State in Nigeria. Ado Ado Ekiti is a city in southwest Nigeria, the state capital and headquarters of the Ekiti State. The population in 2006 was 308,621. The people of Ado Ekiti are mainly of the Ekiti subethnic group of the Yoruba. The Ado people outside their high knowledge in education indulge in farming. They are known for their traditional believe because it is a common practice among the aged, youths and children. Many hospitals are within the Ado town but this has not stopped them from practicing traditional healing where many are renowned traditional healers.

The pants with their local names were identified and also crosschecked and updated with online Google search for confirmation. Ethical approval was obtained from the traditional healers for this study.

${ }^{1}$ Biological Sciences Department, Afe Babalola University, Ado Ekiti, Nigeria, ${ }^{2}$ Biochemistry Department, Afe Babalola University, Ado Ekiti, Nigeria, ${ }^{3}$ School of Sciences, Afe Babalola University, Ado Ekiti, Nigeria, and ${ }^{4}$ Library Department, Afe Babalola University, Ado Ekiti, Nigeria

Address for correspondence: F.C. Akharaiyi, Biological Sciences Department, Afe Babalola University, Ado Ekiti, Nigeria.

Acknowledgement: This study is one of the projects under the Directorate of Technological Development (DTD) of Afe Babalola University, Ado Ekiti. We thank the management for their financial support of this project, the volunteered traditional healers in Ado Ekiti metropolis for their assistance that lead to the collection and identification of valuable plants with antidiabetic properties, there preparations and administration.

\section{Anti-diabetic plants}

Twenty three plant samples were identified for the use in the treatment of diabetes by the herbalists. The plants that are common among the healers are Anthocleista djalonensis, Vernonia amygdalina, Ocimum gratissimum, Momordica charantia. These plants could be common among the healers because they are found all over the places and could be of faster activity than other. Another reason could either be, others are seasonal, or far in the forest to take some kilometres to locate. Most importantly, all the plants are wild species that grow in their natural habitats.

The most preferred method of preparation by the healers is concoction and decoction of fresh leaves, stem or stem bark and roots. Most of these herbal remedies have different dosages and the reason was that some remedies are more concentrated than others and to avoid over dose that could result to dizziness and stomach disorder, care must be managed over dosage.

About $50 \%$ of the healers declared that consumption of too much sugar caused diabetes and they linked they believe to regular drinking of beer, soft drinks and carbohydrate foods. Carbohydrate foods are the staple foods for the common man in Nigeria and Africa as a whole where some families are proudly living on three square meal of no other than carbohydrate.

The traditional healers have common view in the diagnosis of patients with diabetes. Frequent urination, losing of weight and dryness in the throat are the most common symptoms among the healers. As diabetes has different stages, most of the traditional healers, do not attend to patients with chronic stage of infection but refer them to hospital for the fear that the patient might die in the process of treatment. The very poor that cannot afford hospital 
bill stay in their homes and remedies are administered as required to relief or cure them of the illness. When improvement is not certain, they are referred to most experienced herbalist for trial.

\section{Advice from traditional healers on how to prevent diabetes}

- Stop eating carbohydrate foods on regular basis.

- Eat carbohydrate foods with local spiced soups prepared with edible leaves.

- Do not drink beer and soft drinks on regular basis.

- Stop smoking cigarettes.

- Do exercise the body on daily basis by either working in the farm, in compound or on the street.

- Gin, rum and hot drinks are threats and should be avoided.

The plant parts for anti-diabetic preparation were not measured by the traditional healers and the measures by individual healers even varies and therefore was very difficult to evaluate the $\mathrm{mg} / \mathrm{ml}$ or $\mu \mathrm{g} / \mathrm{ml}$ taken by a patient in a dose or to effect healing. Again the chemical compounds in the anti-diabetic herbal formulations are not known and cannot be specified.

The use of medicinal plants in healing diseases is growing every day, despite the modern medicines that are readily available and affordable. This is possible because effective plant materials for healing diseases are accessible and by nature certain families are endowed with spiritual power for the remedies with plants as it is not a business for everyone.

\section{References}

1. IDF Diabetes Atlas. 6th Edition. International Diabetes Federation, 2013. Available at: http://www.idf.org/diabetesatlas.

2. World Health Organization (WHO). Definition, diagnosis and classification of diabetes mellitus and its complications. Part 1: Diagnosis and classification of diabetes mellitus World Health Organization, Geneva, 1999. Report Number: WHO/NCD/NCS/99.2.

3. World Health Organization (WHO) 2015. World Health Statistics 2015 contains WHO's annual compilation of health-related data for its 194 Member States, and includes a summary of the progress made towards achieving the health-related Millennium Development Goals (MDGs) and associated targets.

4. Zuffa M. Letter to the editor: On the problems of the so-called afternoon diabetes. Bratisl Med J 2016; 117 (10): 619. http://dx.doi.org/10.4149/ BLL_2016_120.

Received March 16, 2017. Accepted April 17, 2017. 